\title{
LATVIJAS DIASPORAS UN REMIGRĀCIJAS APJOMA NOVĒRTẼJUMS: METODOLOĢISKĀS PIEEJAS UN GALVENIE ATZINUMI
}

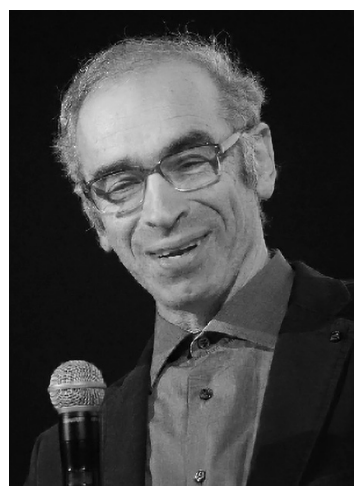

Mihails Hazans, Dr. math., ir LU ekonometrijas profesors un Bonnas Darba pētījumu institūta (IZA Institute of Labor Economics) asociētais pētnieks. Pētījumi skar plašu darba tirgus problēmu spektru, ieskaitot migrāciju, bezdarba risku, bezdarbnieku apmācību, etnisko minoritāšu integrāciju, neformālo nodarbinātību, izglîtības ekonomiku. Vairāk nekā 20 projektos bijis eksperts, konsultants vai padomnieks tādām starptautiskām organizācijām kā Ekonomiskās sadarbības un attīstības organizācija $(O E C D)$, Pasaules Banka, Eiropas Komisija, Eiropas Rekonstrukcijas ağentūra, Eiropas Ekspertīzes centrs darba likumdošanas, nodarbinātības un darba tirgus politikas jomā $(E C E)$ un Starptautiskā Darba organizācija (ILO). Par emigrācijas pētījumiem piešķirta Spīdolas balva ekonomikā (2011), viena no viņa publikācijām par šo tēmu ir iekḷauta Latvijas zinātnes sasniegumu sarakstā (2012). Pašlaik ir vadošais pētnieks LU Filozofijas un sociologijas institūta (LU FSI) projektā Labklājība un integrācija migrācijas kontekstā.
Raksturvārdi: diaspora, emigrācija, remigrācija, pilsonība, etniskā izcelsme.

\section{Ievads}

Diasporas apjoma iespējami precīzs novērtējums ir jebkuras diasporas politikas pamatā, taču dažādu apstākḷ dẹl to novētēet nav viegli jebkurai valstij ${ }^{1}$, un Latvija nav izṇēmums. Grūtîbas sākas jau ar diasporas definīciju, kura atsaucās uz tādu datos dažreiz grūti identificējamu lietu kā saikne ar Latviju. Šajā pētījumā veiktais novērtējums attiecas uz šādiem diasporas segmentiem:

- ārzemēs dzīvojošie Latvijas Republikas (LR) valstspiederīgie (Latvijas pilsoṇi, t. sk. ar dubultpilsonību, un Latvijas nepilsonii);
- ārzemēs dzīvojošie bijušie LR valstspiederīgie (kuri pieṇēmuši citu valstu pilsonību);

- ārzemēs dzīvojošās Latvijā dzimušas² personas (šì grupa pārklājas ar iepriekš minētajām, bet nesakrīt ne ar vienu no tām);

- ārzemēs dzīvojošie LR valstspiederīgo (ieskaitot bijušo) vai Latvijā dzimušo personu pēcteči (t. sk. visi, kas uzskata sevi par latviešiem vai par cilvēkiem ar latviešu vai Latvijas saknēm).

No datu pieejamības skatpunkta var izšķirt divas būtiski atšķirīgas diasporas dal̦as. Pēc neatkarības atjaunošanas aizbraukušie Latvijas emigranti un vinu pēcteči veido t. s. jauno diasporu. Tās pārstāvjiem lielākoties ir vai nu tikai LR pilsonība (vai nepilsoṇa pase),

2 Pēc starptautiski vispārpieṇemtās definīcijas (sk., piem., Eurostat 2019), par Latvijā dzimušām tiek uzskatītas visas personas, kas ir dzimušas Latvijas teritorijā (pēc pašlaik esošām robežām).

\footnotetext{
OECD 2015.
} 
vai (tās vietā vai papildus tai) relatīvi nesen iegūta mītnes zemes pilsonība. Savukārt trimdas latvieši un viņu pēcteči veido t. s. veco diasporu; viniiem lielākoties šobrīd ir vai nu dubultpilsonība, vai tikai mītnes zemes pilsonība, turklāt mītnes zemes pilsonība iegūta vai nu kopš dzimšanas, vai l̦oti sen, laikā, par kuru statistika nav pieejama.

\section{Diasporas mozaīka - kāpēc to tik grūti "saskaitīt"}

Pēc PMLP Iedzīvotāju reǵistra datiem (PMLP 2020), 2020. gada sākumā ārvalstīs dzīvoja 203960 Latvijas pilsoņu un nepilsoņu. Savukārt pēc pēdējiem Ārlietu ministrijas aptuveniem datiem, kas bija pieejami pirms šî pētījuma un kas tika iegūti 2013. gadā, apkopojot pārstāvniecību aplēses un iedzīvotāju reǵistra informāciju, ārpus Latvijas dzīvoja, mācījās un strādāja vairāk nekā 370000 Latvijas diasporas pārstāvju. Gadu gaitā Latvijas medijos bieži izskanēja atšķirīgie diasporas apjoma novērtējumi ${ }^{3}$ ar vai bez atsaucēm uz dažādu institūciju un pētnieku grupu publikācijām. Šajās publikācijās tika pielietotas atšķirīgas metodoloǵiskās pieejas un daudzveidīgie datu avoti, bet lielākoties faktiski tika novērtēts nevis diasporas apjoms konkrētajā gadā, bet migrācijas rezultātā zaudēto Latvijas iedzīvotāju (vai retāk - Latvijas valstspiederīgo) skaits noteiktajā periodā - citiem vārdiem, negatīvais migrācijas saldo. Savukārt mediji (un dažreiz arī paši pētnieki) šo novērtējumu rezultātus interpretēja kā diasporas apjomu. Šì interpretācija var noderēt aplēsēm, bet vairāku iemeslu dēḷ tā nav pilnīgi korekta.

Pirmkārt, šādos gadījumos visbiežāk tika izmantots kopējais (nevis LR valstspiederīgo) migrācijas saldo. Tas nozīmē, ka visi no Latvijas izbraukušie ārvalstnieki tika nepamatoti pieskaitīti pie Latvijas diasporas. Turklāt pēdējos gados Latvijas valstspiederīgo negatīvais migrācijas saldo ir krietni lielāks par kopējo, jo Latvijā iebrauc vairāk ārvalstnieku nekā no Latvijas izbrauc (ārvalstnieku migrācijas saldo ir pozitivvs) ${ }^{4}$.

\footnotetext{
3 Piem., LSM.LV 2017b.

4 CSP 2020a.
}

Otrkārt, arī gadījumā, kad tiek noteikts migrācijas rezultātā zaudēto LR valstspiederīgo skaits, tas nav korekts diasporas apjoma (vai pieauguma) novērtējums, jo neņem vērā ārzemēs dzīvojošo LR valstspiederīgo dzimstību un mirstîbu. Runājot par "jauno" diasporu, dzimstība būtiski pārsniedz mirstību, tāpēc uz migrācijas plūsmām balstītas aplēses novērtē šīs diasporas apjomu zemāk, nekā tas faktiski ir ${ }^{5}$. Piem., Norvēǵijā 2020. gada sākumā no visiem iedzīvotājiem ar Latvijas saknēm gandrīz $18 \%$ bija dzimuši Norvēgijāā . "Vecās" diasporas zemēs ārpus Latvijas dzimušo īpatsvars Latvijas diasporā ir vēl lielāks. Tā pirmās un otrās diasporas paaudzes pārstāvju vidū Zviedrijā 2020. gadā šis īpatsvars bija $35 \%$, bet Austrālijā 2016. gadā $-75 \%{ }^{8}$.

Treškārt, ārvalstnieku imigrācijas uzskaite daudzās valstīs ir stingrākā nekā valstspiederīgo imigrācijas vai ārvalstnieku emigrācijas uzskaite. Tāpēc ārvalstu statistika par imigrantiem - LR valstspiederīgiem (t. i., mūsu emigrantiem) ir piln̄̄gāka nekā par emigrantiem - LR valstspiederīgiem (t. i., mūsu remigrantiem). Rezultātā cilvēks, kurš aizbrauca no Latvijas, pēc gada atgriezās, bet vēl pēc gada atkal aizbrauca, var plūsmu statistikā parādīties kā divi migrācijas rezultātā zaudētie cilvēki (ja atgriešanas fakts netika piefiksēts).

Var secināt, ka diasporas apjoms jānovērtē ar tiešām metodēm, pamatojoties uz datiem par Latvijas pilsoņu un nepilsoņu, kā arī Latvijā dzimušo personu un to pēcteču skaitu ārvalstīs. Svarīgi apzināties, ka pilsonības kritērijs nevar būt vienīgais, jo daḷai trimdas latviešu un viṇu pēcteču, kā arī daliai pēc neatkarības atjaunošanas aizbraukušo Latvijas emigrantu un vinu pēcteču šobrīd nav Latvijas pilsonības. Tāpēc loti vērtīgi ir dati par latviešu skaitu un/ vai latviešu izcelsmes personu skaitu valstīs, kur tāda informācija ir pieejama.

5 Līdzīgas problēmas pastāv gadījumos, kad migrācijas saldo novērtējumam tiek izmantota nevis migrācijas plūsmu statistika, bet Latvijā dzīvojošo valstspiederīgo skaita izmaiņas vecuma kohortu ietvaros (Hazans 2016a, 2018, 2019) vai gaisa transporta pasažieru skaita statistika (Krasnopjorovs 2011; Hazans 2013).

6 Statistics Norway 2020.

7 Statistics Sweden 2020 un autora aprēḳini.

8 Goldmanis 2020; 
Jautājums par etnisko izcelsmi (ethnic ancestry) ir, piem., Amerikas kopienu apsekojuma (American Community Survey ${ }^{9}$, ASV) anketā, kā arī tautas skaitī̌sanas anketās Austrālijā $\bar{a}^{10}$ un Kanādā $\overline{1}^{11}$, turklāt publiski pieejamos datos var nodalīt: (i) personas, kurām latviešu izcelsme ir minēta kā pirmā vai vien̄igā; (ii) personas, kuras minēja latviešu izcelsmi kā otro vai vienu no vairākām. No, otras puses, Ziemelvalstu un Nīderlandes statistikas biroji attiecībā uz imigrantiem un to pēctečiem izmanto izcelsmes valsts (country of origin; country background; migration background) jēdzienu ${ }^{12}$.

Fokuss uz diasporas izpētei atbilstošajiem datiem diemžēl arī negarantē vieglu ceḷu diasporas apjoma un struktūras apzināšanas procesā. Pirmkārt, datu pieejamība stipri atšķiras pa valstīm. Otrkārt, daḷa nepieciešamo datu dažām valstīm ir pieejama tikai no tautas skaitīšanas (TS) datiem, un ši pētījuma tapšanas laikā jaunākie TS dati Eiropā lielākoties bija par 2010.-2011. gadu. Treškārt, viens un tas pats Latvijas valstspiederīgais dažādos datu avotos var būt uzskaitīts ka Latvijā dzīvojošs (uz deklarācijas pamata) un kā ārzemes dz̄̄vojošs (pēc faktiskas dzīvesvietas). Ceturtkārt, ārvalstīs dzīvojošie Latvijas pilsoņi (vai bijušie Latvijas pilsonii) ar mìtnes valsts pilsonību šīs valsts iedzīvotāju statistikā nav uzskaitîti kā ārvalstnieki.

Līdzīgas problēmas saistītas arī ar remigrantu uzskaiti, apgrūtinot remigrācijas atbalsta pasākumu plānošanu un to efektivitātes novērtējumu. Informācija par remigrācijas apjomu ir pieejama no dažādiem datu avotiem: Centrālās statistikas pārvaldes (CSP) statistika par remigrantiem ${ }^{13}$, CSP Ārējās migrācijas apsekojums $^{14}$, Darbaspēka apsekojums ${ }^{15}$, Ienākumu un dzīves apstākḷu apsekojums ${ }^{16}$. Katram no tiem ir savi ierobežojumi, un, tikai kombinējot

\footnotetext{
9 Dati pieejami caur IPUMS USA 2020.

10 Australian Bureau of Statistics 2017.

11 Statistics Canada 2017.

12 Statistics Denmark 2020; Statistics Norway 2020.

13 CSP 2019b, 2020b.

14 CSP 2019c, 2019d.

15 CSP 2019e.

16 CSP 2019f.
}

novērtējumus no visiem šiem avotiem, iespējams iegūt labāko šobrīd iespējamo remigrācijas apjoma novērtējumu.

Papildus jau ierastajām migrācijas fakta uzskaites problēmām izaicinājumu diasporas un remigrantu apjoma novērtējumam rada arvien pieaugošais migrantu skaits, ko raksturo transnacionāls jeb "plūstošs" dzīvesveids ${ }^{17}$. Grūtības rada arī neskaidras "diasporas" un "remigrantu" definīcijas un arī starptautiskajā iedzīvotāju statistikā sastopamās "emigrantu" definīciju atškirības $^{18}$. Remigrantu uzskaiti īpaši apgrūtina tas, ka daļai remigrantu vai repatriantu nav Latvijas pilsonības, tādēl statistikā viņi var parādīties kā imigranti - ārvalstnieki.

\section{Diasporas apjoms un struktūra - datu avoti un galvenie atzinumi}

Šajā pētîjumā diasporas apjoma un struktūras novērtējumam tika izmantoti šādi galvenie datu avoti:

- Eiropas Savienības (ES) un Ekonomiskās sadarbības un attīstības organizācijas (ESAO, angl. OECD) dalībvalstu statistika par Latvijas valstspiederīgo skaitu, kā arī Latvijā dzimušo personu skaitu ES un ESAO valstīs ${ }^{19}$.

- ES un ESAO dalībvalstu statistika par to Latvijas pilsonu skaitu, kuri ieguvuši kādas ES vai ESAO valsts pilsonību 1995.-2019. gadā. ${ }^{20}$

- ESAO statistika ${ }^{21}$ par Latvijā dzimušām personām ESAO un citās valstīs.

- Austrālijas, Īrijas un Kanādas 2016. gada (un iepriekšējo gadu) tautas skaitīšanas dati ${ }^{22}$, kā arī ASV 2018. gada (un

17 Koroḷeva, Mieriṇa 2015, 11; Hazans 2016b, 12, 15-16; LSM.LV (2017a).

18 Hazans 2013; Goldmanis, 2015.

19 Apkopotā veidā šî statistika ir pieejama no Eurostat un OECD: Eurostat 2020a-2020c; OECD 2016, 2018, 2020; papildus tam tika izmantoti arī nacionālo statistikas biroju dati.

${ }^{20}$ Eurostat 2020d; OECD 2020.

21 OECD 2018; Dumont et. al. 2010.

${ }^{22}$ Australian Bureau of Statistic 2017; CSO 2017a, 2017b; Statistics Canada 2017. 
iepriekšējo gadu) Amerikas kopienu apsekojuma (American Community Survey) dati. ${ }^{23}$

- CSP ilgtermiṇa starptautiskās migrācijas statistika (t. sk. pilsonības un tautības griezumā). ${ }^{24}$

- CSP 2017.-2018. gada Ārējās migrācijas apsekojuma rezultāti, kā arī mikrodati. ${ }^{25}$

- Pilsonības un migrācijas lietu pārvaldes (PMLP) 2006.-2020. gada dati par to ārvalstīs dzīvojošo LR valstspiederīgo skaitu, kuri nav deklarējuši dzīvesvietu Latvijā. ${ }^{26}$

- Krievijas, Ukrainas un Baltkrievijas pēdējās tautas skaitīšanas rezultāti par latviešu tautības un Latvijā dzimušiem iedzīvotājiem. ${ }^{27}$

Svarīgi atzīmēt, ka dažu šo avotu dati balstās uz izlases apsekojumiem un tāpēc ietver statistisko kḷūdu. Piem., Lielbritānijā dzīvojošo Latvijas valstspiederīgo skaits ir zināms ar statistisko kḷūdu 15 tūkst. cilvēku ${ }^{28}$. Tāpēc rezultātu robustuma pārbaudes nolūkā 1. tabula sniedz diasporas apjoma novērtējumu pēc trīs pēdējo pieejamo gadu datiem ${ }^{29}$.

${ }^{23}$ Dati pieejami caur IPUMS USA 2020.

${ }^{24}$ CSP 2019a, 2020a.

${ }^{25}$ CSP 2019c, 2019d.

26 PMLP 2020.

27 Belstat 2010; Rosstat 2013, 2018; Minnesota Population Center (2019); OECD 2018.

${ }^{28}$ Office for National Statistics (2020).

${ }^{29}$ Pētîjuma tapšanas laikā dati par Latvijas diasporas apjomu 2020. gada sākumā bija pieejami par Dāniju, Somiju, Norvēgiju, Zviedriju (sk. Statistics Denmark 2020; Statistics Finland 2020; Statistics Norway 2020; Statistics Sweden 2020) un Lielbritāniju (Office for National Statistics 2020; Home Office 2020). Pēc 1. tabulas (2) un (3) slejas definīcijām, Latvijas diasporas apjoms četrās iepriekš minētajās Ziemeḷvalstīs bija gandrīz par 5\% lielāks nekā gadu iepriekš. Attiecībā uz kopējo diasporas apjomu pārējās ES un ESAO valstīs (bez Lielbritānijas) tika pieņemts 4\% pieaugums; tas ir piesardzīgs pienēmums, jo katrā no iepriekšejjiem trīs gadiem (2017-2019) šajā valstu grupā Latvijas diasporas pieaugums bija vai nu lielāks nekā četru Ziemeḷvalstu grupā, vai arī atpalika mazāk nekā par vienu procentpunktu, un vidējais pieaugums bija lielāks. Visbeidzot, tika pieņemts, ka Latvijas diasporas apjoms ārpus ES un ESAO 2020. gada sākumā bija tāds pats kā 2019. gada sākumā.
Gan 2018. gada sākumā, gan 2020. gada sākumā ārvalstīs dzīvoja ap 300 tūkst. Latvijas valstspiederīgo un bijušo valstspiederīgo, t. sk. ap 280 tūkst. - ES un ESAO valstīs (1. tabula, sleja (2)). Savukārt, ieskaitot arī visas Latvijā dzimušas personas (neatkarīgi no tā, vai tām iepriekš bija LR pilsonība) ${ }^{30}$, diasporas apjoms nedaudz pārsniedzis 390 tūkst., t. sk. ap 295 tūkst. - ES un ESAO valstīs (1. tabula, slejas (2), (3)). 2019. gada sākumā novērtētais valstspiederīgo diasporas apjoms bija par aptuveni 10 tūkst. mazāks nekā pirms gada (pieejamie dati liecina, ka 2018. gadā ap 18 tūkst. Latvijas valstspiederīgo atstāja Lielbritāniju; daḷa no tiem bija atgriezušies Latvijā, dalı pārcēlās uz citām ārvalstīm, bet netika iekḷauti šo valstu 2019. gada sākuma datos).

Izmantojot pieejamus datus par ASV, Austrālijā, Kanādā, Ziemel̦valstīs un Nīderlandē dzīvojošiem etniskiem latviešiem un cilvēkiem, kuriem abi vecāki dzimuši Latvijā, dokumentētais Latvijas diasporas apjoms 2018.-2020. gadā svārstās robežās 440 449 tūkst. cilvēku, t. sk. 340-350 tūkst. - ES un ESAO valstīs (1. tabula, sleja (4)). Pieskaitot vēl datus par citām personām ar latviešu vai Latvijas saknēm (galvenokārt ASV, Kanādā un Austrālijā, mazākā apjomā - arī Ziemel̦valstīs un Nīderlandē), Latvijas diasporas apjoms pasaulē 2018.-2020. gada sākumā pārsniedz pusmiljonu, t. sk. pāri par 400 tūkst. - ES un ESAO valstīs (1. tabula, sleja (5)).

${ }_{30} \breve{S}_{1}$ soḷa tehniskā izpilde variē atkarībā no datu pieejamības dažādās valstīs. Ja ir pieejami mikrodati vai ir iespējams tiešsaitsē veikt mikrodatu tabulācijas, tad tabulācija pēc pazīmēm "Dzimšanas valsts Latvija" un "Pilsonības valsts - Latvija" sniedz vēlamo rezultātu. Pretējā gadījumā katrā vecuma un dzimuma grupā tiek salīdzināts Latvijā dzimušo skaits un Latvijas pilsoṇu skaits un tiek izmantots lielākais no skaițiem. Saskaitot iegūtos rezultātus pa visām vecuma un dzimuma grupām, iegūst diasporas apjoma novērtējumu, kurš pārsniedz gan Latvijas valstspiederīgo skaitu, gan Latvijā dzimušo personu skaitu konkrētajā valstī. Visbeidzot, ja kādā valstî dati nav pieejami vecuma un dzimuma griezumā, bet kopējais identificēto Latvijas valstspiederīgo un bijušo valstspiederīgo skaits ir mazāks nekā Latvijā dzimušo skaits, tad pēdējais tiek izmantots diasporas novērtējumam. 
1. tabula. Latvijas diasporas apjoms gada sākumā, 2018-2020 (tūkst. cilvēku)

\begin{tabular}{|c|c|c|c|c|c|}
\hline & $\begin{array}{c}\text { PMLP } \\
\text { dati }\end{array}$ & $\begin{array}{l}\text { LR VPD un } \\
\text { bij. VPD }\end{array}$ & $\begin{array}{l}\text { LR VPD, bij. VPD un } \\
\text { Latvijā dzimušie }\end{array}$ & $\begin{array}{l}\text { Plašā } \\
\text { diaspora - 1 }\end{array}$ & $\begin{array}{l}\text { Plašāa } \\
\text { diaspora - 2 }\end{array}$ \\
\hline & $\mathbf{( 1 )}$ & $\mathbf{( 2 )}$ & $\mathbf{( 3 )}$ & $\mathbf{( 4 )}$ & $\mathbf{( 5 )}$ \\
\hline & \multicolumn{5}{|c|}{ ES + ESAO } \\
\hline 2018 & 171 & 280 & 296 & 348 & 407 \\
\hline 2019 & 183 & 269 & 286 & 342 & 404 \\
\hline 2020 & 194 & 277 & 294 & 351 & 412 \\
\hline & & & Visa pasaule & \\
\hline 2018 & 180 & 303 & 393 & 445 & 504 \\
\hline 2019 & 193 & 292 & 384 & 440 & 502 \\
\hline 2020 & 204 & 300 & 392 & 449 & 510 \\
\hline
\end{tabular}

Piezīmes. (1) - LR valstspiederīgo (pilsoṇu, t. sk. ar dubultpilsonību, un nepilsoṇu) skaits ārvalstīs pēc PMLP datiem (neiekḷauj personas, kuru dzīvesvieta ir deklarēta Latvijā); (2) - LR valstspiederīgo (t. sk. ar dubultpilsonību), kā arī bijušo valstspiederīgo skaits ārvalstīs; (3) - LR valstspiederīgo un bijušo valstspiederīgo, kā arī Latvijā dzimušo personu skaits ārvalstīs; (4) - papildus (3) iekḷauti cilvēki, kuri norādīja latviešu (vai Latvijas) izcelsmi kā savu pirmo vai vien̄̄go etnisko izcelsmi (dati pieejami par ASV, Austrāliju un Kanādu), kā arī cilvēki, kuriem abi vecāki dzimuši Latvijā (dati pieejami arī par Dāniju, Somiju, Nīderlandi, Norvēǵiju un Zviedriju); (5) - papildus (4) iekḷauti cilvēki, kuri norādīja latviešu (vai Latvijas) izcelsmi kā savu otro vai vienu no vairākām izcelsmēm (dati pieejami par ASV, Austrāliju un Kanādu), kā arī cilvēki, kuriem viens no vecākiem dzimis Latvijā, u. c. Latvijā dzimušo personu pēcnācēji (dati pieejami arī par Dāniju, Somiju, Nīderlandi, Norvēgiju un Zviedriju). ES ir ES-28 bez Latvijas. 2020. gada dati ir provizoriski, sk. zemsvītras piezīmi $^{30}$. Avoti: autora aprēḳini, izmantojot datus no avotiem, kuri minēti tekstā pirms šīs tabulas.

Izmantojot datus no iepriekš minētajiem avotiem, Hazans (2020, 3. attēls) ieguva diasporas apjoma ES un ESAO valstīs novērtējumus pa gadiem (no 2000. gada sākuma līdz 2020. gada sākumam), piemērojot vairākas diasporas definīcijas (t. sk. 1. tabulas sleju (1)-(3) definīcijas). Rezultāti liecina, ka vienīgi 2018. gadā novērtētais diasporas apjoms piedzīvoja sarukumu, savukārt visstraujākais diasporas pieaugums tika novērots 2004.-2007. un 2009.-2013. gadā.

Latvijas diasporas apjoma novērtējumi galvenajās valstu grupās 2019. gada sākumā ir apkopoti 2. tabulā (rezultātus pa valstīm sk. Hazans 2020, P2.-P3. tabula). Latvijas valstspiederīgo un bijušo valstspiederīgo diasporas apjoms ES valstīs bija 218 tūkst., Eiropas Brīvās tirdzniecības asociācijas (EBTA) ${ }^{31}$ valstīs - 17 tūkst., ESAO valstīs ārpus Eiropas (lielākoties - ASV, Austrālijā un Kanādā) 34 tūkst., bijušās Padomju Savienības republikās -20 tūkst. un citur -3 tūkst. (2. tabula,

31 Eiropas Brīvās tirdzniecības asociācijas (angl. European Free Trade Association (EFTA)) dalībvalstis ir Islande, Lihtenšteina, Norvēgija un Šveice. sleja (2)). Savukārt plašās diasporas dokumentētais apjoms bija 230 tūkst. ES valstīs, 18 tūkst. EBTA valstīs, 156 tūkst. ESAO valstīs ārpus Eiropas, 95 tūkst. bijušās Padomju Savienības republikās un 3 tūkst. citur (2. tabula, sleja (5)).

Diezgan liela "jaunās” diasporas daḷa joprojām oficiāli dz̄̄vo Latvijā ${ }^{32}$. Salīdzinot ārvalstu un PMLP statistiku par ārvalstīs dzīvojošiem Latvijas valstspiederīgiem, var secināt, ka 2018. gada sākumā ES un EBTA valstīs dzīvoja vismaz 95 tūkst. Latvijā deklarēto LR pilsoņu un nepilsoņu; 2019. gada sākumā šis skaits saruka līdz 64 tūkst. (lielākoties uz Lielbritānijas rēķina, kur breksita gaidās daudzi Latvijas pilsoṇi anulēja dzīvesvietas deklarāciju Latvijā, lai pieteiktos Lielbritānijas pastāvīga iedzīvotāja statusam).

2016. gadā gandrīz 55 tūkst. Latvijā dzimušo ESAO valstu iedzīvotāju (t. i., 22\% no Latvijā dzimušo diasporas ESAO valstīs) bija mītnes zemes pilsonība. Mītnes valstu pilsoņu ipatsvars pieaug ar vecumu: no $6 \%$ bērnu vidū

\footnotetext{
${ }^{32}$ Sk. Helmane 2019.
} 
2. tabula. Latvijas diasporas apjoms valstu grupās, 2019. g. sākums (tūkst. cilvēku)

\begin{tabular}{|r|c|c|c|c|c|}
\hline & $\begin{array}{c}\text { PMLP } \\
\text { dati }\end{array}$ & $\begin{array}{l}\text { LR VPD un } \\
\text { bij. VPD }\end{array}$ & $\begin{array}{l}\text { LR VPD, bij. } \\
\text { VPD un Latvijā } \\
\text { dzimušie }\end{array}$ & $\begin{array}{l}\text { Plašā } \\
\text { diaspora-1 }\end{array}$ & $\begin{array}{l}\text { Plašāas } \\
\text { diaspora-2 }\end{array}$ \\
\hline & $\mathbf{( 1 )}$ & $\mathbf{( 2 )}$ & $\mathbf{( 3 )}$ & $\mathbf{( 4 )}$ & $\mathbf{( 5 )}$ \\
\hline ES + ESAO & 183,2 & 269,1 & 285,7 & 341,7 & 403,7 \\
\hline ES-28 & 144,3 & 218,1 & 225,8 & 226,5 & 230,0 \\
\hline EBTA & 6,3 & 17,0 & 17,0 & 17,0 & 17,7 \\
\hline ESAO ārpus & & & & & \\
\hline ES-28 un EBTA & 32,6 & 34,0 & 42,9 & 98,2 & 156,0 \\
\hline Bij. Padomju & & & & & \\
\hline Savienība & 7,4 & 20,0 & 95,0 & 95,0 & 95,0 \\
\hline Citas Eiropas & & & & & 0,2 \\
\hline valstis & 0,2 & 0,2 & 0,2 & 0,2 & 0,2 \\
\hline Pārējā pasaule & 1,8 & 3,0 & 3,0 & 3,0 & 3,0 \\
\hline Pavisam & 192,6 & 292,3 & 384.0 & 439,9 & 501,9 \\
\hline
\end{tabular}

Piezīmes. Sk. 1. tabulas piezīmes. Avoti: autora aprēḳini, izmantojot datus no avotiem, kuri minēti tekstā pirms 1. tabulas.

līdz $11 \%$ jauniešu ${ }^{33}$ vidū un $16 \%$ vecumgrupā 25-64 gadi; savukārt senioru vidū gandrīz 90\% ir mītnes zemes pilsonība. Sieviešu ar mītnes zemes pasēm ir krietni vairāk nekā vīriešu.

Pēc stāvokḷa uz 2019. gada sākumu, vairāk nekā 25 tūkst. Latvijas valstspiederīgo laikā no 1994. līdz 2018. gadam ieguva kādas citas ES vai ESAO valsts pilsonību, t. sk. pāri par septiniem tūkst. - ASV pilsonību, gandrīz pieci tūkst. - Lielbritānijas pilsonību, pāri par trīs tūkst. - Vācijas pilsonību, aptuveni divi tūkst. - Kanādas, Zviedrijas un Īrijas pilsonību. Turklāt vairāk nekā 11 tūkst. Latvijas valstspiederīgo laikā no 1992. līdz 2015. gadam ieguva Krievijas pilsonību ${ }^{34}$.

Kopumā Latvijas valstspiederīgo un bijušo valstspiederīgo diasporā ES un ESAO valstīs "jaunās" diasporas pārstāvju ar mītnes zemes pilsonību ìpatsvars ir 8\%, taču dažās zemēs tas ir krietni lielāks: 47\% ASV, 46\% Jaunzēlandē, 39\% Kanādā, 21\% Zviedrijā, 12-17\% Itālijāa, Somijā, Šveicē un Polijā. Latvijas nepilson,u ipatsvars Latvijas valstspiederīgo diasporās pasaulē ir 3,7\%.

33 Šajā rakstā jaunieši ir cilvēki vecumā no 15 līdz 24 gadiem.

34 Autora aprēksini, izmantojot 2015. gada Krievijas tautas mikroskaitīšanas rezultātus no Rosstat (2018).

\section{Latvieši un latviešu valoda diasporā}

Pēc pēdējiem pieejamiem datiem, ASV dzīvo ap 90 tūkst. cilvēku ar latviešu saknēm ${ }^{35}$, Kanādā - pāri par 30 tūkst. $^{36}$, bet Austrālijā pāri par 20 tūkst. ${ }^{37}$ Pieņemot, ka cilvēki, kuri uz jautājumu par savu izcelsmi kā pirmo vai vien̄̄go izvēlas atbildi Latvian, uzskatāmi par (etniskiem) latviešiem, no tiem pašiem datu avotiem izriet, ka latviešu skaits ASV vērtējams ap 30 tūkst., Kanādā ap 7 tūkst., Austrālijā - pāri par 9 tūkst. 21. gadsimtā aizbraukušo Latvijas valstspiederīgo vidū latviešu īpatsvars dažādos periodos bija robežās no 50 līdz 60 procentiem ${ }^{38}$; tas nozīmē vismaz 150 līdz 180 tūkst. ārzemēs dzīvojošo latviešu, kuri atstāja dzimto zemi pēdējo 20 gadu laikā (šis novērtējums neiekḷauj viṇu bērnus, kas piedzimuši ārvalstīs).

Vairāk nekā puse Latvijā dzimušo etnisko latviešu un gandrīz trīs ceturtdaḷas citu Latvijā dzimušo ASV iedzīvotāju, kam ir latviešu saknes, mājās runā latviski. Savukārt vairākums ārpus Latvijas dzimušo latviešu un citi, kam ir latviešu saknes, mājās runā angliski. Tātad

\footnotetext{
${ }^{35}$ Autora aprēkinini, izmantojot American Community Survey 2018 datus no IPUMS USA 2020.

36 Statistics Canada 2017.

37 Australian Bureau of Statistics 2017.

${ }^{38}$ Hazans 2016a; CSP 2020a; Hudenko 2020.
} 
diasporā ar paaudžu maiņu notiek latviešu valodas (kā mājas valodas) dal̦ēja aizstāšana ar anglı valodu. Kopumā pāri par 70\% etnisko latviešu un $90 \%$ citu ASV iedzīvotāju, kam ir latviešu saknes, mājās runā angliski, savukārt galvenokārt latviski mājās runā 21\% etnisko latviešu un tikai $1 \%$ citu iedzīvotāju ar latviešu saknēm. ${ }^{39}$ Ārpus ASV dzimušie latvieši, kuri ieradās ASV pēdējo 20 gadu laikā, lieto latviešu valodu mājās biežāk nekā tie, kas ASV nodzīvoja vairāk nekā 20 gadus. No otras puses, latviešu un angḷu valodas izplatības ziṇā nav lielu atškiirību starp latviešiem, kuri nodzīvoja ASV līdz 5 gadiem, 6-15 gadus un $16-20$ gadus. $^{40}$

Kanādā 2016. gadā bija 6,5 tūkst. latviski runājošo, t. sk. 5,5 tūkst. ar dzimto latviešu valodu, bet tikai 1,3 tūkst. ( $18 \%$ no visiem latviešiem) to lietoja kā mājas valodu ${ }^{41}$. Savukārt Austrālijā 2016. gadā mājās galvenokārt latviski runāja gandrīz puse (48\%) Latvijā dzimušo latviešu, bet tikai 19\% no ārpus Latvijas dzimušiem latviešiem (t. i., 2. paaudzes diasporas). Pavisam kopā latviski mājās runāja ap 3 tūkst. cilvēku (14\% no visiem ar latviešu saknēm), t. sk. ap 2,5 tūkst. latviešu ( $28 \%$ no visiem latviešiem). ${ }^{42}$

Pēc "Latvijas emigrantu kopienas" 2019. gada 2. viḷna aptaujas datiem, 70\% "jaunās" diasporas pārstāvju ar dzimto latviešu valodu lietoja latviešu valodu mājās, t. sk. $38 \%$ kā vienīgo, 10\% - kopā ar krievu valodu un $22 \%$ - kopā ar anglu vai citu mītnes zemes valodu. Tie, kas pavadīja mìtnes zemē vairāk nekā 10 (un it sevišķi vairāk nekā 15) gadus, latviešu valodu lieto retāk, bet angḷu (vai citu valodu, iznemot krievu) valodu - biežā $k^{43}$. Tātad, līdzīgi kā ASV, Kanādā un Austrālijā, visā latviešu diasporā pakāpeniski notiek latviešu valodas aizstāšana ar mītnes zemes valodu.

${ }^{39}$ Hazans 2020, izmantojot American Community Survey 2018 datus no IPUMS USA 2020.

${ }^{40}$ Hazans 2020, izmantojot American Community Survey 2017-2018 datus no IPUMS USA 2020.

${ }^{41}$ Statistics Canada 2017 dati un autora aprēḳini.

42 Australian Bureau of Statistics 2016, 2017; Goldmanis 2020; autora aprēḳini.

${ }^{43}$ Hazans 2020. Par valodas lietošanu diasporā sk. arī M. Hazana intervijā Hudenko 2020.
Krievijā 2010. gadā dzīvoja ap 19 tūkst. latviešu, no tiem latviešu valodu prata 6650 (35\%); tajā pašā laikā latviešu valodas zināšanas bija vēl 15 tūkst. citu tautību pārstāvju (nav zināms, cik no tiem bija ar latviešu saknēm) ${ }^{44}$. Latviešu valodas pratēju skaits Krievijā saruka no 35 tūkst. 2002. gadā līdz 22 tūkst. 2010. gadā. ${ }^{45}$ Pēdējie pieejamie dati par latviešu skaitu Krievijā nāk no 2015. gada tautas mikroskaitīšanas; vispārinot mikroskaitîšanas rezultātus uz visu iedzīvotāju kopu, iegūst provizorisko vērtējumu: ap 13 tūkst. latviešu ${ }^{46}$. Savukārt Baltkrievijā 2009. gadā dzīvoja nedaudz vairāk par 1,5 tūkst. latviešu (svaigākie dati sagaidāmi no 2020. gada tautas skaitī̌sanas).

\section{Diasporas demogrāfiskais portrets}

Dzimuma struktūras ziṇā Latvijas diaspora kopumā ir līdzsvarota: sieviešu īpatsvars dažādos diasporas segmentos ir robežās no $51 \%$ līdz 55\%. Starp Latvijas valstspiederīgajiem Eiropā bērnu īpatsvars ir tāds pats kā Latvijā (16\%), jauniešu īpatsvars nedaudz lielāks (12\% pret $9 \%)$, bet vidējā vecuma (25-44 gadi) iedzīvotāju īpatsvars ir divreiz lielāks nekā Latvijā (55\% pret 27\%); resp., daudz mazāks nekā Latvijā ir iedzīvotāju īpatsvars vecumgrupās 45-64 gadi un it îpaši $65+$ gadi. Latvijas diaspora Eiropā kopumā ir jaunāka nekā Latvijas iedzīvotāji ${ }^{47}$.

Turpretim Latvijā dzimušo un etnisko latviešu diasporās ASV un Kanādā kodolu veido "vecā" diaspora, tāpēc senioru (65+) īpatsvars ir ap 30\% ASV un pārsniedz $40 \%$ Kanādā. ${ }^{48}$

Lai salīdzinātu tieksmi pārcelties ar bērniem uz dzīvi ārzemēs un/vai radīt bērnus ārzemēs Latvijas diasporās dažādās valstīs, tika aprēķināts bērnu skaits uz 100 pieaugušajiem

\footnotetext{
44 Rosstat 2013.

45 Rosstat 2004; Rosstat 2013.

46 Autora aprēkinini, izmantojot Rosstat 2018 datus.

47 Autora aprēksini, izmantojot datus no Eurostat 2020a, 2020b.

48 Autora aprēķini, izmantojot Statistics Canada 2017 un American Community Survey 2018 datus no IPUMS USA 2020.
} 
vecumā 15-49 gadi $^{49}$. Visaugstākās šī rādītāja vērtības (ap 45) ir ASV un Kanādā starp jauktas izcelsmes personām ar latviešu un citām saknēm. Starp etniskajiem latviešiem ASV ir 25 bērni uz 100 pieaugušajiem vecumā 15-49 gadi, kas tikai nedaudz pārsniedz vidējo rādītāju starp Latvijā dzimušiem un Latvijas valstspiederīgajiem ES un EBTA valstīs (22 bērni uz 100 pieaugušajiem), savukārt starp etniskajiem latviešiem Kanādā rādītājs ir daudz zemāks (15 bērni uz 100 pieaugušajiem $)^{50}$. Latvijas iedzīvotāju vidū 2018. gada sākumā bija 36 bērni uz 100 pieaugušajiem vecumā 15-49 gadi $^{51}$, bet salīdzināt šo rādītāju ar iepriekš minētajiem diasporas rādītājiem nebūtu korekti, jo pieejamajos datos neparādās daḷa diasporas bērnu - gan tie, kas ir dzimuši ārvalstīs un uzreiz ieguvuši mītnes zemes vai citu (ne Latvijas) pilsonību, gan tie, kas palikuši Latvijā ar vienu no vecākiem vai citiem radiniekiem. Kopumā šis jautājums prasa dziḷāku izpēti.

2018. gada sākumā Latvijas diasporā ES un EBTA valstīs bija vairāk nekā 37 tūkst. bērnu vecumā līdz 15 gadiem, ASV - 13,2 tūkst. bērnu (t. sk. gandrīz 7 tūkst. latviešu un pāri par 6 tūkst. citu ar latviešu saknēm), Kanādā 2016. gadā - 5,5 tūkst. bērnu ar latviešu saknēm. ${ }^{52}$

Pēc OECD apkopotajiem datiem ${ }^{53}$, 2016. gada sākumā nedaudz vairāk par ceturtdaḷu no visiem Latvijā dzimušiem pieaugušajiem ESAO valstīs pavadīja mītnes zemē līdz 5 gadiem (ieskaitot); katrs trešais Latvijā dzimušais vīrietis un gandrīz katra trešā sieviete mītnes zemē nodzīvoja no 5 līdz 10 gadiem; divas piektdaḷas Latvijas diasporas pieaugušo locekḷu mītnes zemē nodzīvoja vairāk nekā 10 gadus.

Lielāku detalizāciju pa periodiem, turklāt dzimuma, tautības un pilsonības griezumā

49 Dati attiecas uz 2018. gada sākumu; izņēmums ir Kanāda - tai izmantoti 2016. gada dati.

50 Autora aprēkini, izmantojot datus no Eurostat 2020a, 2020b; Statistics Canada 2017; IPUMS USA 2020.

51 Autora aprēḳini, izmantojot CSP datus.

52 Autora aprēķini, izmantojot CSP datus.

53 Autora aprēḳini, izmantojot datus no OECD 2018. sniedz šim pētījumam sagatavotie (iepriekš nepublicētie) CSP dati par 2012.-2018. gadā emigrējušiem Latvijas valstspiederīgajiem, kuri 2019. gada sākumā dzīvoja ārpus Latvijas ${ }^{54}$. Septinu gadu laikā (2012-2018) uz dažādām pasaules zemēm aizbraukuši un līdz perioda beigām nav atgriezušies vairāk nekā 113 tūkst. Latvijas valstspiederīgo, t. sk. 53 tūkst. - 2012.2014. gadā, ap 33 tūkst. - 2015.-2016. gadā un gandrīz 28 tūkst. - 2017.-2018. gadā.

Gada vidējais emigrējušo un līdz 2019. gada sākumam neatgriezušos skaits pakāpeniski samazinājās no 17,8 tūkst. 2012.-2014. gadā līdz 13,8 tūkst. 2017.-2018. gadā. Sieviešu īpatsvars šajā diasporas daḷā visu laiku bija ap $50 \%$, latviešu īpatsvars vidēji bija 55\%, pieaugot no $50 \%$ perioda sākumā līdz gandrīz $60 \%$ 2017.-2018. gadā, bet nepilsoņu ìpatsvars vidēji bija 6\%.

2016. gadā augstskolu beidzēju īpatsvars Latvijā dzimušo citu ESAO valstu iedzīvotāju vidū vecumgrupā 25-64 gadi bija lielāks nekā tā paša vecuma Latvijas iedzīvotāju vidū. Vienlaikus diasporā šajā vecumgrupā ir lielāks nekā Latvijā arī cilvēku ar zemu izglītības līmeni īpatsvars. Savukārt jauniešu vidū diasporā ir gan lielāks nekā Latvijā augstskolu beidzēju īpatsvars, gan mazāks tādu personu īpatsvars, kurām ir tikai pamatizglīitība. Vislielākais augstskolu beidzēju îpatsvars, kā arī vismazākais personu ar zemu izglīî̄bu īpatsvars ir atrodams starp tiem, kas mītnes zemē nodzīvojuši vairāk nekā 10 gadus. Savukārt tie, kas mîtnes zemē pavadījuši līdz 5 gadiem (t. i., iebrauca 2011.-2015. gadā), ir labāk izglītoti nekā tie, kas iebrauca iepriekšējos 5 gados. Tas liecina par smadzeņu aizplūdes intensifikāciju periodā pēc ekonomiskās krīzes $(2011-2015)^{55}$.

\section{Remigrācijas izpētes izaicinājumi}

Diasporas likuma ${ }^{56}$ izpratnē remigrācija ir "diasporas locekl̦a atgriešanās vai pārcelšanās no pastāvīgas dzīves ārvalstīs uz pastāvīgu dzīvi Latvijā”. Nemot vērā ārkārtīgi

\footnotetext{
54 CSP 2019a.

55 Autora aprēķini, izmantojot datus no OECD 2018. Sk. arī Hazans 2015a, 2016a, 2018.

56 LR Saeima 2018.
} 
plašu un "iekl̦aujošo" diasporas locekḷa definīciju, Diasporas likumā iestrādātā konceptuālā izpratne par remigrāciju nedod iespēju kaut cik precīzi novērtēt remigrācijas apjomu. Praktiskajos nolūkos lietderīgāk izmantot CSP remigranta definīciju: "Latvijas valsts piederīgais (pilsonis, nepilsonis vai Latvijā dzimusi persona $)^{57}$, kurš bijis emigrācijā un imigrējis atskaites gadā." 'S̄ì definīcija neietver ārpus Latvijas dzimušos cilvēkus, kas ir latvieši, bet nav Latvijas pilsoni. Šīs definīcijas svarīgs aspekts ir tas, ka "bijis emigrācijā" CSP izpratnē nozīmē, ka cilvēks bijis starptautiskais ilgtermiña emigrants, t. i., "persona, kura izbrauc uz citu valsti pastāvīgās dzìvesvietas maiñas nolūkā vai vismaz uz vienu gadu”. Praktiski tas nozīmē, ka CSP datos ieklautie remigranti ir Latvijas valstspiederīgie, kuri atgriezās Latvijā pēc vismaz viena gada prombūtnes.

Literatūrā un starptautiskajos apsekojumos sastopamās remigranta definīcijas parasti ietver divus svarīgus parametrus (kritērijus): (1) minimālais ārvalstīs nepārtraukti nodzīvotais laiks - tas var būt viens gads (kā CSP definīcijā), 6 mēneši vai 3 mēneši; (2) references periods - parasti tas ir pēdejjie 5 vai 10 gadi. Ja remigranti tiek identificēti aptaujas datos, tad atbilstošais jautājums varētu būt formulēts apmēram šādi: "Vai pēdējo 10 gadu laikā Jūs dzīvojāt ārvalstīs vismaz 6 mēnešus bez pārtraukumiem?"; līdzīgs variants tiek izmantots apsekojumā European Social Survey (ESS). Remigrantus var identificēt, arī izmantojot registru datus (kā to dara CSP), bet arī tad atbilstošie kritēriji ir ieprogrammēti. Ja remigrantu identificēšanai tiek izmantots apsekojums, kurā mērkgrupā remigranti nav nodalīiti kā atsevišķa kategorija, ārvalstīs nepārtraukti nodzīvotā laika kritērijs var tikt aizvietots ar nosacījumu, ka cilvēks ārzemēs strādājis - tipiski (kaut ne vienmēr) tas nozīmēs, ka tur nodzīvoti vismaz 3 mēneši; references periods šādos gadījumos ir atkarīgs no datu struktūras un var būt īsāks nekā 5 gadi.

Svarīgi saprast, ka remigrantu skaita novērtējuma rezultāts ir bütiski atkarīgs no

57 Šajā rakstā termins "Latvijas valstspiederīgais" tiek izmantots nedaudz šaurākā nozīmē (LR pilsonis vai nepilsonis) nekā CSP termins "Latvijas valsts piederīgais". abiem pieminētiem remigranta definīijas parametriem - ārvalstīs nepārtraukti nodzīvotā laika un references perioda. Samazinoties pirmajam vai pieaugot otrajam no šiem parametriem, pieaug definīcijai atbilstošo remigrantu skaits.

\section{Remigrācijas apjoms un struktūra - datu avoti un galvenie atzinumi}

2016. gada sākumā Latvijā bija 100 līdz 118 tūkst. 18-74 gadus veco remigrantu, kuri iepriekšèjo 10 gadu laikā (2006-2015) strādāja ārvalstīs vismaz 6 mēnešus pēc kār$\operatorname{tas}^{58}$. Savukārt 2020. gada sākumā Latvijā dzīvoja 145 lìdz 187 tūkst. remigrantu vecumā 18-74 gadi, kuri iepriekšèjo 10 gadu laikā (2010-2019) veikuši kādu algotu darbu citā valstī 6 mēnešus vai ilgāk. Šis vērtējums iegūts, izmantojot Eiropas sociālā apsekojuma 9. vilna Latvijas datus ${ }^{59}$.

CSP publicētie dati par ikgadējām Latvijas valstspiederīgo remigrantu plūsmām (remigrantu skaits pa gadiem, sākot ar 2011. gadu, kā arī remigrantu demogrāfiskais portrets, sākot ar 2013. gadu ${ }^{60}$ nedod iespēju precīzi novērtēt, cik 2020. gada sākumā Latvijā bija remigrantu, kuri kopš 2011. gada nepārtraukti nodzīvoja ārvalstīs vismaz gadu. Iemesls ir tas, ka daži no šiem remigrantiem atkal aizbrauca un nedzīvo Latvijā, bet daži citi šajos datos parādās vairākkārt. Tātad, saskaitot gadu plūsmas, iegūst tikai remigrantu skaita augšējo robežu: tādu remigrantu, kuri atgriezās Latvijā 2011.-2019. gadā, pirms tam vismaz vienu gadu pavadot ārvalstīs, ir ne vairāk $k \bar{a}$ 58,4 tūkst. ${ }^{61}$

Pēc autora pieprasījuma CSP ir sagatavojusi arī datus par 2015.-2018. gada remigrantiem, kuri 2019. gada 1. janvārī, pēc

\footnotetext{
${ }^{58}$ Hazans 2016b, 2020. Iepriekš remigrantu skaita novērtējumi tika sniegti darbos Hazans 2008, 2011, 2015a, 2015b, 2016a.

59 European Social Survey 2020 un Hazans 2020. Ticamības intervāls ir plašāks nekā iepriekš, jo izlases apjoms bija mazāks.

${ }^{60}$ CSB 2020a, 2020b.

${ }^{61}$ Hazans 2020.
} 
CSP novērtējuma, dzīvoja Latvijā ${ }^{62}$, un tas dod iespēju novērtēt Latvijā palikušo neseno remigrantu skaitu: 2019. gada sākumā Latvijā dzīvoja 12670 pieaugušo (vismaz 15 gadus veco) remigrantu, kas atgriezās Latvijā 2015.-2018. gadā, pirms tam vismaz vienu gadu pavadot ārvalstīs. Šo remigrantu vidū $53 \%$ ir vīrieši, $58 \%$ ir latvieši un $90 \%$ ir Latvijas pilsoņi.

Saskaitot 2015.-2018. gada tās pašas vecuma kohortas remigrantu plūsmu apjomus, iegūst 17 428. Ignorējot iespēju, ka daži remigranti šo 4 gadu laikā bija atgriezušies vairākkārt, tas nozīmē, ka no 2015.-2018. gada remigrantiem (dzimušiem 2004. gadā vai agrāk) 2019. gada sākumā Latvijā dzīvoja aptuveni trīs ceturtdalıs.

Šajā pētījumā remigrācijas apjoma novērtējumam tika izmantoti arī no CSP iegūtie Darbaspēka apsekojuma (DSA) mikrodati un EU-SILC (Ienākumu un dzīves apstākḷu apsekojuma) mikrodati63. EU-SILC datos var identificēt tos LR valstspiederīgos, kuriem kādā no iepriekšējiem 4 gadiem bija (bet aptaujas gadā nav) ienākumi no algota darba ārzemēs, bet DSA datos - tos, kuri strādāja ārzemēs iepriekšējo 15 mēnešu laikā. Izslēdzot jūrniekus un valsts pārvaldes darbiniekus (tie, visticamāk, bija nosūtītie darbinieki, nevis emigranti), iegūti šãdi rezultāti:

- 2017. gadā Latvijā dzīvoja 30 tūkst., bet 2018. gadā - 34 tūkst. šādu remigrantu ar iepriekšējo 4 gadu laikā ārzemēs gūto darba pieredzi;

- no 2013. līdz 2018. gadam katru gadu Latvijā atgriezās 10 līdz 11 tūkst. remigrantu, kuri iepriekšejā gadā strādāja ārzemēs; salīdzinājumam: CSP novērtētās ikgadējās remigrantu plūsmas (piemērojot 12 mēnešu prombūtnes kritēriju) ir 5 līdz 6 tūkst. remigrantu gadā, t. sk. 3,5 līdz 4 tūkst. darbspējas vecumā;

- no 2008. līdz 2018. gadam Latvijā kā remigranti atgriezās 53 tūkst. unikālo personu ar iepriekšējo 15 mēnešu laikā

${ }^{62}$ CSP 2019b. Šo datu references periods faktiski ir 4 gadi. Tā nav kritiska problēma, jo no politikas viedokḷa svarīgi ir tieši pēdējo dažu gadu remigranti.

${ }^{63}$ CSP 2019e, 2019f. ārzemēs gūto darba pieredzi un 117 tūkst. unikālo personu ar iepriekšējo 4 gadu laikā ārzemēs gūto darba pieredzi.

\section{Nobeigums}

Šajā rakstā sniegtais diasporas apjoma novērtējuma metožu kritiskais pārskats liecina, ka diasporas apjoms jānovērtē ar tiešām metodēm, par pamatu izmantojot nevis migrācijas plūsmu vai transporta pasažieru plūsmu statistiku, bet datus par Latvijas valstspiederīgo (pilsoņu un nepilsoņu) un bijušo valstspiederīgo, kā arī Latvijā dzimušo personu un to pēcteču skaitu ārvalstīs. Pilsonības kritērijs nevar būt vienīgais, jo daḷai trimdas latviešu un viņu pēcteču, kā arī dal̦ai pēc neatkarības atjaunošanas aizbraukušo Latvijas emigrantu un vinu pēcteču nav Latvijas pilsonības, turklāt dažiem arī nekad nebija Latvijas pilsonības.

Diasporas apjoma un struktūras apzināšanu apgrūtina vairāki apstākḷi:

- viens un tas pats Latvijas valstspiederīgais dažādos datu avotos var būt uzskaitīts kā Latvijā dzīvojošs (uz deklarācijas pamata) un kā ārzemes dzīvojošs (pēc faktiskas dzīvesvietas);

- ārvalstīs dzīvojošie Latvijas pilsoņi (vai bijušie Latvijas pilsoņi) ar mîtnes valsts pilsonību šis valsts statistikā nav uzskaitīit kā ārvalstnieki;

- daudzās valstīs nav pieejama informācija par Latvijā dzimušo personu pēcnācējiem;

- arvien pieaug to cilvēku skaits, kuriem raksturīgs transnacionāls dzīvesveids.

Līdzīgas problēmas saistītas arī ar remigrantu uzskaiti.

Gan diasporas apjoma, gan remigrācijas apjoma novērtējumam nepieciešams kombinēt daudzveidīgus datus no dažādiem avotiem.

2018. gada sākumā un 2020. gada sākumā ārvalstīs dzīvoja ap 300 tūkst. Latvijas valstspiederīgo un bijušo valstspiederīgo, t. sk. ap 280 tūkst. - ES un ESAO valstīs, ap 20 tūkst. - bijušās Padomju Savienības republikās un ap 3 tūkst. - citur. Ieskaitot arī visas Latvijā dzimušas personas, diasporas apjoms nedaudz pārsniedzis 390 tūkst., t. sk. ap 295 tūkst. - ES un ESAO valstīs un 95 tūkst. bijušās Padomju Savienības republikās. 
Pieskaitot vēl datus par citām personām ar latviešu vai Latvijas saknēm (galvenokārt - ASV, Kanādā un Austrālijā, mazākā apjomā - arī Ziemeḷvalstīs un Nīderlandē), Latvijas diasporas apjoms pasaulē 2018.-2020. g. sākumā pārsniedz pusmiljonu, t. sk. pāri 400 tūkst. - ES un ESAO valstīs.

Remigrantu skaita novērtējuma rezultāts ir būtiski atkarīgs no abiem remigranta definīcijas parametriem - ārvalstīs nepārtraukti nodzīvotā laika un references perioda. Turklāt vairāki neatkarīgie datu avoti liecina, ka nozīmīga daḷa remigrantu atkārtoti izbrauc no Latvijas.

2019. gada sākumā Latvijā dzīvoja 12,7 tūkst. pieaugušo remigrantu, kas atgriezās Latvijā 2015.-2018. gadā, pirms tam vismaz vienu gadu pavadot ārvalstīs. Pavisam tādu remigrantu, kuri atgriezās Latvijā 2011.2019. gadā, pirms tam vismaz vienu gadu pavadot ārvalstīs, ir ne vairāk kā 58,4 tūkst. (daḷa no viṇiem, iespējams, atkal aizbrauca no Latvijas).

EU-SILC apsekojuma mikrodatu analīze liecina, ka no 2008. līdz 2018. gadam Latvijā atgriezās kā remigranti 117 tūkst. unikālo personu ar iepriekšējo 4 gadu laikā ārzemēs gūto darba pieredzi, bet 2018. gadā Latvijā dzīvoja vien 34 tūkst. šādu remigrantu (abos gadījumos netiek piemērots nosacījums, ka ārvalstīs bija nepārtraukti jānodzīvo vismaz gads). Savukārt Eiropas sociālā apsekojuma dati liecina, ka 2020. gada sākumā Latvijā dzīvoja vismaz 145 tūkst. tādu remigrantu vecumā 18-74 gadi, kuri iepriekšējo 10 gadu laikā (2010-2019) veikuši kādu algotu darbu citā valstī 6 mēnešus vai ilgāk.

Raksts tapis Fundamentālo un lietišķo pētījumu programmas projekta Labklājība un integrācija migrācijas kontekstā (LZP grants Nr. LZP-2018/1-0042) ietvaros; projektu īsteno LU Filozofijas un sociologijas institūtā. Datu vākšanu un apstrādi finansēja Ārlietu ministrija LU Diasporas un migrācijas pētījumu centra projektā Diasporas un migrācijas pétījumu centra (DMPC) pasākumu īstenošana 2019. gadā. Pētījuma Diasporas apjoma novērtējums detalizētu izklāstu sk. Hazans 2020.

\section{VĒRES}

Australian Bureau of Statistics (2016) Census of Population and Housing: TableBuilder. Pieejams: https:// www.abs.gov.au/websitedbs/d3310114.nsf/home/about+tablebuilder. (10.05.2020.).

Australian Bureau of Statistics (2017) Census of Population and Housing: Reflecting Australia - Stories from the Census, 2016 - Cultural Diversity. Pieejams: https://www.abs.gov.au/ausstats/abs@.nsfl Latestproducts/3415.0Main\%20Features42020? opendocument\&tabname $=$ Summary\&prodno $=3415.0$ $\&$ issue $=2020 \&$ num $=\&$ view $=(10.05 .2020$. $)$.

Belstat (2010) 2009. g. tautas skaitiššanas rezultāti. Iedzīvotāju skaits un sastāvs. Statistiskais biḷetens (krievu valodā). Pieejams: https://www.belstat.gov.by/informatsiya-dlya-respondenta/perepis-naseleniya/perepis-naseleniya-2009-goda/statisticheskie-publikatsii/statisticheskie-byulleteni/index_544/ (10.05.2020.).

CSO (2017a) Census 2016 - Non-Irish Nationalities Living in Ireland. Pieejams: https://www.cso.ie/en/ releasesandpublications/ep/p-cpnin/cpnin/ (10.05.2020.).

CSO (2017b) Census of Population 2016 - Profile 7 Migration and Diversity. Pieejams: https://www.cso.ie/ en/releasesandpublications/ep/p-cp $7 \mathrm{md} / \mathrm{p} 7 \mathrm{md} /(10.05 .2020$.).

CSP (2019a) Pēc LU pieprasījuma sagatavotie dati par 2015.-2018. gada emigrantiem - Latvijas pilsoṇiem un nepilsoņiem, kā arī citām Latvijā dzimušām personām, kuras, pēc CSP novērtējuma, 2019. gada sākumā dzīvoja ārpus Latvijas.

CSP (2019b) Pēc LU pieprasījuma sagatavotie dati par 2015.-2018. gada remigrantiem - Latvijas pilsoņiem un nepilsoṇiem, kā arī citām Latvijā dzimušām personām, kuras, pēc CSP novērtējuma, 2019. gada sākumā dzīvoja Latvijā.

CSP (2019c) Ārējās migrācijas panelapsekojuma rezultāti. Preses relīze. Pieejams: https://www.csb.gov.lv/ lv/statistika/statistikas-temas/iedzivotaji/migracija/meklet-tema/2618-arejas-migracijas-panelapsekojuma-rezultati (10.05.2020.).

CSP (2019d) Pēc LU pieprasījuma sagatavotie 2017.-2018. gada Ārējās migrācijas paneḷapsekojuma mikrodati. 
CSP (2019e) Pēc LU pieprasījuma sagatavotie Darbaspēka apsekojuma (EU LFS) mikrodati.

CSP (2019f) Pēc LU pieprasījuma sagatavotie EU-SILC apsekojuma mikrodati.

CSP (2020a) Starptautisko ilgtermiņa migrantu vecuma un dzimuma struktūra, etniskais sastāvs, gimenes stāvoklis un valstiskā piederība, 2011-2019 (tabulas IBG040 - IBG043).

CSP (2020b) Remigrantus raksturojošie rādīiāji, 2013-2019 (tabulas IBG200 - IBG230).

Dumont, J.-C.; Spielvogel, G.; Widmaier, S. (2010). International Migrants in Developed, Emerging and Developing Countries: An Extended Profile. OECD Social, Employment and Migration Working Papers No. 114. Pieejams: www.oecd.org/els/workingpapers.

European Social Survey (2020). Data and documentation. Pieejams: https://www.europeansocialsurvey.org/ data/ (18.06.2020.).

Eurostat (2019) EU legislation on the 2021 population and housing censuses - Explanatory notes. Luxembourg : Publications Office of the European Union, doi:10.2785/513433.

Eurostat (2020a) Population on 1 January by age group, sex and citizenship (migr_pop1ctz).

Eurostat (2020b) Population on 1 January by age group, sex and country of birth (migr_pop3ctb).

Eurostat (2020c) EU and EFTA citizens who are usual residents in another EU/EFTA country as of 1 January (migr_pop9ctz).

Eurostat (2020d) Acquisition of citizenship by age group, sex and former citizenship (migr_acq).

Goldmanis, M. (2015) Statistisko svaru dizains pētījumā "Latvijas emigrantu kopienas". I. Mieriņa (red.) Latvijas emigrantu kopienas: cerību diaspora. Rīga : LU Filozofijas un socioloǵijas institūts, 42-65. Pieejams: https://dspace.lu.lv/dspace/handle/7/31738 (10.05.2020.).

Goldmanis, M. (2020) Ar tiešsaistes tabulatoru iegūtie rezultāti no Austrālijas 2016. gada tautas skaitīšanas. Privātā komunikācija.

Hazans, M. (2008) Post-Enlargement Return Migrants' Earnings Premium: Evidence from Latvia. Paper presented at EALE Conference 2008, Amsterdam, 18-20 September 2008. Pieejams: https://ssrn.com/ abstract $=1269728$ (10.05.2020.).

Hazans, M. (2011) Latvijas emigrācijas mainīgā seja: 2000-2010. B. Zepa, E. Kḷave (red.) Latvija. Pārskats par tautas attīstību 2010//2011. Nacionālā identitāte, mobilitāte un rīcībspēja, 70-91. Rīga : LU Akadēmiskais apgāds. Pieejams: https://dspace.lu.lv/dspace/handle/7/31240 (10.05.2020.).

Hazans, M. (2013) Emigration from Latvia: Recent trends and economic impact. OECD. Coping with Emigration in Baltic and East European Countries. OECD Publishing (2013), 65-110. Pieejams: https:// doi.org/10.1787/9789264204928-en (10.05.2020.).

Hazans, M. (2015a) Smadzeņu aizplūde no Latvijas 21. gadsimtā. I. Mierina (zin. red.) Latvijas emigrantu kopienas: cerību diaspora. Rīga : LU Filozofijas un socioloǵijas institūts, 85-92. Pieejams: https:// dspace.lu.lv/dspace/handle/7/31738.

Hazans, M. (2015b) Emigrācija no Latvijas 21. gadsimtā reǵionu, pilsētu un novadu griezumā. I. Mieriņa (red.) Latvijas emigrantu kopienas: cerību diaspora. Rīga : LU Filozofijas un sociologijas institūts, 11-25. Pieejams: https://dspace.lu.lv/dspace/handle/7/31738 (10.05.2020.).

Hazans, M. (2016a) Migration experience of the Baltic countries in the context of Economic Crisis. M. Kahanec, K. F. Zimmermann (eds.) Labor Migration, EU Enlargement, and the Great Recession. Berlin-Heidelberg: Springer, doi: 10.1007/978-3-662-45320-9 13.

Hazans, M. (2016b) Atgriešanās Latvijā. Remigrantu aptaujas rezultāti. LU Diasporas un migrācijas pētījumu centrs. Pieejams: http://www.diaspora.lu.lv/fileadmin/user_upload/lu_portal/projekti/diaspora/ petijumi/Atgriesanas_Latvija_-_petijuma_zinojums.pdf (10.05.2020.).

Hazans, M. (2018) Labour Market Policy Thematic Review 2018: An in-depth analysis of the emigration of skilled labour. Latvia. Brussels : European Commission, Directorate-General for Employment, Social Affairs and Inclusion. European Centre of Expertise (ECE), 2018. Pieejams: https://www.researchgate. net/publication/328912663 (10.05.2020.).

Hazans, M. (2019) Emigration from Latvia: A Brief History and Driving Forces in the Twenty-First Century. R. Kaša and I. Mierina. The Emigrant Communities of Latvia: National Identity, Transnational Belonging and Diaspora Politics. Springer, 35-68. Pieejams: https://link.springer.com/chapter/10.1007/978-3-030-12092-4_3 (19.06.2020.).

Hazans, M. (2020) Diasporas apjoma novērtējums. Pētījuma rezultāti. LU Diasporas un migrācijas pētījumu centrs. Pieejams: https://www.diaspora.lu.lv/fileadmin/user_upload/lu_portal/projekti/diaspora/ petijumi/Diasporas apjoma novertejums - Zinojums.pdf.

Helmane, I. (2019) Deklarējušies, bet Latvijā nedzìvo. LV portāls. Pieejams: https://lvportals.lv/ norises/301243-deklarejusies-bet-latvija-nedzivo-2019 (10.05.2020.). 
Home Office (2020) EU Settlement Scheme Statistics, April 2020. Pieejams: https://assets.publishing. service.gov.uk/government/uploads/system/uploads/attachment_data/file/886174/eu-settlement-schemestatistics-april-2020.pdf.

Hudenko, K. (2020) Nelatvieši aizbrauc biežāk, jo neapmierināti ar politiku un nekur nerod mājas, izpētījis Hazans. DELFI Intervija ar Mihailu Hazanu. Delfi (15.06.2020.). Pieejams: https://www.delfi.lv/ delfi-plus/latvija/nelatviesi-aizbrauc-biezak-jo-neapmierinati-ar-politiku-un-nekur-nerod-majas-izpetijis-hazans.d? $i d=52224807$ (19.06.2020.).

IPUMS USA (2020), University of Minnesota. Pieejams: www.ipums.org (10.05.2020.).

Koroḷeva I.; Mieriṇa, I. (2015) Uzticamas informācijas par Latvijas emigrantiem un remigrantiem iegūšanas pētnieciskie risinājumi. Akadēmiskā Dzīve, 51, 6-23.

Krasnopjorovs, O. (2011) Cik cilvēku Latviju pameta, un cik vēl pametīs? Pieejams: https://www.macroeconomics.lv/node/388 (10.05.2020.).

LR Ārlietu ministrija (2019) Informācija tautiešiem ārzemēs. Pieejams: https://www.mfa.gov.lv/moscow/ tautiesiem/informacija-tautiesiem-arzemes (10.05.2020.).

LR Saeima (2018) Diasporas likums. Pieejams: https://likumi.lv/ta/id/302998-diasporas-likums (10.05.2020.).

LSM.LV (2017a) Intervija ar LU profesoru Mihailu Hazanu par aizbraucējiem un tiem, kas tomēr atgriežas. Pieejams: https://www.lsm.lv/teta-projekts/intervija/intervija-ar-latvijas-universitatesprofesoru-mihailuhazanu (10.05.2020.).

LSM.LV (2017b) Pēc neatkarības atjaunošanas Latviju pametuši 600 tūkstoši iedzīvotāju. Pieejams: https:// www.lsm.lv/teta-projekts/dati/pec-neatkaribas-atjaunosanas-latviju-pametusi-600-tukstosi-iedzivotaju (10.05.2020.).

Minnesota Population Center (2019) Integrated Public Use Microdata Series, International: Version 7.2 [dataset]. Minneapolis, MN: IPUMS, 2019. Pieejams: https://doi.org/10.18128/D020.V7.2 (10.05.2020.).

OECD (2015) Connecting with Emigrants: A Global Profile of Diasporas 2015. OECD Publishing, Paris. Pieejams: https://doi.org/10.1787/9789264239845-en.

OECD (2016) Immigrants in OECD countries (Edition 2015). OECD International Migration Statistics (database). Pieejams: https://doi.org/10.1787/fc58e93c-en (10.05.2020.).

OECD (2018) The Database on Immigrants in OECD and non-OECD countries - DIOC: OECD-AFD. Pieejams: http://www.oecd.org/els/mig/dioc.htm (10.05.2020.).

OECD (2020) International migration database. OECD International Migration Statistics (database). Pieejams: https://doi.org/10.1787/data-00342-en (10.05.2020.).

Office for National Statistics (2020) Population of the UK by country of birth and nationality. Pieejams: https://www.ons.gov.uk/peoplepopulationandcommunity/populationandmigration/internationalmigration/datasets/populationoftheunitedkingdombycountryofbirthandnationality.

PMLP (2020) Latvijas valstspiederīgo personu skaits ärvalstīs, 2006.-2020. g. Pieejams: https://www.pmlp. gov.lv/lv/sakums/statistika/iedzivotaju-registrs/ (10.05.2020.); https://www.pmlp.gov.lv/lv/sakums/statistika/iedzivotaju-registrs/arhivs.html (10.05.2020.).

Rosstat (2004) 2002. gada tautas skaitǐšanas rezultāti (krievu valodā), 4. sējums. Pieejams: http://www. perepis2002.ru/index.html? id $=17$.

Rosstat (2013) 2010. gada tautas skaitī̌sanas rezultāti (krievu valodā), 4. un 8. sējums. Pieejams: https:// gks.ru/free_doc/new_site/perepis2010/croc/perepis_itogi1612.htm (10.05.2020.).

Rosstat (2018) 2015. gada tautas mikroskaitǐšanas rezultāti (krievu valodā), 7., 8. un 10. nodaḷa. Pieejams: https://gks.ru/free_doc/new_site/population/demo/micro-perepis/finish/micro-perepis.html (10.05.2020.).

Statistics Canada (2017) Immigration and Ethnocultural Diversity Highlight Tables, 2016 Census. Pieejams: https://www12.statcan.gc.ca/census-recensement/2016/dp-pd/hlt-fst/imm/index-eng.cfm.

Statistics Denmark (2020) FOLK2: Population 1. January by country of origin, time, citizenship, ancestry and sex. Pieejams: https://www.statistikbanken.dk/statbank5a/SelectVarVal/Define. asp? Maintable $=$ FOLK2\& PLanguage $=1$ (10.05.2020.).

Statistics Finland (2020) Population structure. Pieejams: http://pxnet2.stat.fi/PXWeb/pxweb/en/StatFin/StatFin_vrm_vaerak/?tablelist=true (02.06.2020.).

Statistics Norway (2020). Population by immigrant category and country background. Pieejams: https:// www.ssb.no/en/befolkning/statistikker/innvbef (10.06.2020.).

Statistics Sweden (2020) Population statistics. Pieejams: https://www.scb.se/en/findingstatistics/statistics-bysubject-area/population/population-composition/populationstatistics/\#_TablesintheStatisticalDatabase (10.06.2020.). 